\title{
Fundamentals of Digital Didactics: Specifics and Development at the Present Stage
}

\author{
Svetlana Bezoluk ${ }^{1, *}$,Elena Azarko ${ }^{1}$, Irina Danchenko ${ }^{2}$, and Igor Kupriyanov ${ }^{1,3}$ \\ ${ }^{1}$ Don State Technical University, Gagarin sq., 1, 344003, Rostov-on-Don, Russia \\ ${ }^{2} \mathrm{NF}$ «PGU», Ul. Kunikova str., 47-B, 353920, Novorossiysk, Russia \\ ${ }^{3}$ Southern Federal University, Bolshaya Sadovaya str., 105/42, 344006, Rostov-on-Don, Russia
}

\begin{abstract}
A theoretical review of research and publications on digitalization of the educational space, including digital didactics, is presented. The authors consider the theoretical aspects of the definition of "digital didactics" in the light of recent domestic and foreign studies. The novelty of this study lies in the characterization of the main trends in the problem of digital didactics, highlighting several problems that modern Russian teachers face in the process of digital learning. The authors draw attention to the need to consider the basics of digital didactics in the context of meaning formation. More than 55 publications of domestic and foreign researchers were studied. The issues of defining the concept of digital didactics are considered, the General characteristics of digital didactics at the present stage, the most important problems and prospects for its study are given. This article will allow researchers working in the field of digital didactics to get acquainted with the most well-known concepts of digital learning today.
\end{abstract}

\section{Introduction}

Digitalization of Russian education, supported at the state level, draws researchers 'views to the systematization of approaches, concepts, and research on digital didactics, and consideration of its specifics in the period from the beginning of the XXI century to the present. Didactics (from the Greek "teaching", "referring to learning") is traditionally understood as a branch of pedagogy that considers the theory of education and training. Its subject is the theory of education and training (regularities, principles, content, goals, form and methods, means, learning outcomes, organization of the educational process). Several factors contributed to the emergence of the concept of digital didactics: first, Russia's integration into the global educational space, which requires accelerating the digitalization of education, due to cross-cultural interaction. Secondly, the global changes in modern society associated with the current epidemiological situation not only in Russia, but also in the world, and the associated changes in the educational process, the transition from fulltime to distance learning, a kind of "challenge of the modern world". The new digital age requires pedagogy to rethink traditional didactic foundations, introduce new innovative digital technologies, and develop electronic resources that can skillfully combine learning

* Corresponding author: sveta-ya7@ya.ru 
goals, content, and results. Thirdly, a special socio-psychological characteristics of the modern young generation (the so-called generation $\mathrm{Y} / \mathrm{Z}$ ): "mosaic" thinking, the inability to focus on one thing for a long time, impatience, reluctance to engage in repetitive activities, but the ability for parallel processing of different information, here are just some of the reasons for introducing new projects, concepts, didactic approaches. Fourth, considering learning as a "two-pronged process", it is impossible not to say about the changing role of a modern teacher. Having become a kind of "teacher-engineer"," teacher-designer", equipped with a huge number of digital tools, practicing various pedagogical approaches, and most importantly, he strives to" keep up " with constantly changing trends. Teachers need to constantly improve their digital competencies in the current conditions with a proactive effect.

In the context of digitalization of education, classical (traditional) didactics is undergoing a process of modification and transformation of its historically established components. The transition from cognitive-knowledge pedagogy to pedagogy that initiates the formation of meaning in students requires focusing primarily on the personal and semantic development of students. The need to bring knowledge closer to real life, create conditions for personal choice in the complex conditions of an ever-changing world, create prerequisites for considering digital didactics in the context of meaning formation.

The factors discussed above actualize the issue of systematization of scientific knowledge of the basics of "digital didactics", consideration of its specifics and development at the present stage.

\section{Goal and objectives}

The aim of the work is: first, to identify and characterize the term "digital didactics" among similar categories describing the process of digitalization of education; second, to identify the range of current problems associated with increase of the information flow of publications; third, to form prospects for further research.

\section{Methods}

The main method is the analysis of foreign and domestic publications for the last decade (2010-2020). In total, more than 55 sources were examined - publications of research results, reports of leading universities on websites about the results of their conferences.

\section{Analysis of publications}

Many conferences, round tables, and studies are currently devoted to this topic not only in Russia, but also abroad. The dominant topic of discussion is the prospects and difficulties of digital transformation of education. Leading Universities of the country (MSU, St. Petersburg state University, HIGHER SCHOOL OF ECONOMICS, RANEPA) (data from the site https: / /vuzopedia.ru/rate-) have been holding conferences dedicated to the digital transformation of education for several years. Their goal is to outline the range of problems of digitalization, as well as outline prospects for further research.

Founded in 2018, the series of monographs of HSE's edited by I. Yu., Uvarov, defines the range of problems facing the Russian education, the priority projects in the field of digitalization, the direction of the research work, presents the international experience of digitalization, how countries such as Finland, Korea, Singapore, etc., are searching for ways to bridge the digital divide [1]. Since the beginning of the pandemic, the number and quality of school education platforms has increased. The analysis of the platforms operating 
in Russia for 2020 allowed us to state that most developers choose testing sites, conduct experiments, and generally move in line with global educational achievements. These are the following platforms: Yaklass, MESH, NES, Foxford, and Yandex.Tutorial and others. During the pandemic, the rapid analysis of digital educational resources and platforms for remote work was created to help General school principals [2]. From our point of view, the Personalized model of Education (PMO) by Sberbank's charitable Foundation "Contribution to the Future" is of the greatest interest [3]. Its peculiarity is flexibility, personalization of the educational process, the ability to create conditions not only for learning, but also for the development and upbringing of the individual. "Being the master of his own learning", the student creates his own individual trajectory, moves at a convenient pace. Working on the platform is based on modules, which is different from the regular system of other platforms. In the light of recent domestic research, the concept of digital vocational education and training is of the greatest interest. The concept developed by RANEPA (2020) defines the possibilities of using it as a basis for determining priority research areas in the field of digital didactics, preparing methodological recommendations, programs, forming assessment criteria, and tools for teachers ' work in the context of digitalization [4]. L. V. Snegireva identifies approaches to e-learning didactics, considers the conceptual and categorical apparatus of digital didactics, and prospects for the development of e-learning principles [5]. M. Choshanov defines modern didactics as the science, engineering, and art of learning, and teachers as designers and developers of educational products (courses, modules, and tasks on the platform). The main goal is to develop an effective digital educational environment [6]. A. N. Pechnikov in his work "Edidactics: who, why and in what form it is needed" raises questions about the prospects for the development of e-learning, presents didactics schemes before digitalization and after its appearance [7]. Similar in terms of problems is the research of Dvoryanchikov N. V., Kalashnikov T. V., Pechnikova L. S., Frolov N. V. [8]. The authors show the specifics, prerequisites, and problems of using digital resources in Russian Universities. The empirical study is based on a survey of students and teachers.

A modern teacher has to deal with a huge number of electronic resources, the number of which is increasing every day. In order to stay afloat, it is necessary to possess "digital competencies". At the faculty of psychology of Lomonosov Moscow State University, a model was developed that includes four types of digital competencies [9]. Research of mental functions of the so-called "digital generation", mechanisms of personality formation, the emergence of new phenomena in the" digital world" that require further research. The problem of forming digital competencies in semantic didactics remains unexplored; only a few researchers raise this issue [10].

Among foreign studies, the works of D.Kergel, and B.Heidkamp-Kergel (2020) are of the greatest interest. The authors suggest integrating the theory and practice of digital-based learning, designing the educational process, and also reveal the prospects for e-learning. The paper presents theoretical and practical recommendations [11].

A systematic review of foreign studies on the problems of this article was conducted by Rodrigues, HH., Almeida, F., Figueiredo, V. \& Lopes, S.L.. After analyzing 99 academic articles from 2010 to 2018 , the authors identified four dominant topics in foreign articles, the most relevant to the subject, and derived the author's definition of electronic didactics [12]. The principles and technologies of e-learning are discussed in the publications of foreign articles researched by the authors [13-22].

The above theories, research and experience are, on the one hand, examples of "embedding" the traditional pedagogy and education in the processes of digitalization of society. On the other hand, they demonstrate the influence of gamification as an approach with its own methods, technologies, and rules for organizing the virtual world, on learning processes and related pedagogy and didactics [23]. 
The analysis of domestic and foreign publications has shown that despite numerous publications, most of them raise issues of digitization of vocational training. Concepts and project development are carried out in leading higher education institutions Russia and abroad.

\section{Results and discussion}

\subsection{On the definition of the concept of "digital didactics"}

Let us consider approaches to definition of the concept of "digital didactics". V.I. Blinov offers the designation of the term as "a branch of pedagogy, scientific discipline on the organization of the learning process in the digital society", as the transfer-integrative area of scientific knowledge [4]. M. Choshanov defines didactics of the digital century as the "edidactics" [6]. This approach is based on D'Angelo G From's research, which suggests considering digital didactics as a type of didactics using information and communication technologies. [25] A similar definition is given by I. N. Frolov "calling digital didactics" a modern form of learning in the XXI century, which studies the laws, regularities, principles and means of e-learning. The very process of learning using network interaction systems is called "E-learning" [26].

E. V.Shirshov combines pedagogy and electronic technologies, approaches the definition of "electronic didactics" [27]. Let us note that the search for the semantic aspect of the concept has been conducted since the end of the XX century, for example, A. A. Andreev, V. I. Soldatkin. A.V. Khutorskoy defining the basics of distance learning, introduce the term "didactics of distance learning", used by some researchers until now [28]. Researchers E. Y. Ilaltdinova T. K. Belyaeva, T. K. Lebedeva introduce the term "digital pedagogy", raise the problems of the term evolution in the conceptual apparatus of pedagogy [29]. A. N. Pechnikov, A. N. Shikov, A. I. Bashmakov, V. A. Pozdnyakov, B. V. Kramarenko -"computer didactics" [30].

In most modern foreign studies, the term we understand as "digital didactics" is considered as "E-learning"or "E -Didactics". For the first time this term was proposed by F..Fischer, as a merger of educational processes with digital technologies . The authors note that in foreign studies there is a merger of such approaches to the definition as "elearning"," virtual learning", " learning with digital resources" E-Learning in foreign studies refers to: mixed (hybrid learning) [31], electronic (Electronic learning), online learning, distance learning. For Example, D. Kergel, which considers the practical and theoretical possibilities of e-learning, equates the terms "E-learning" and "E-Didactics" [11]. Separately in foreign publications is the concept of "Digital didactics" [32-38]. Transformation of the concept of "digital didactics " was the object of research by V. I. Toktarova and A. E. Shpak. Researchers pay attention to the formation of a new term "digital pedagogy", considering it synonymous with the terms " electronic pedagogy"," virtual pedagogy", and "technopedagogy" [39] . In our opinion, these concepts cannot be considered synonymous.

It is worth referring to the often-used term "digital education" today, which is not synonymous with "digital didactics" and "digital learning" [40]

Summarizing the above, we can draw the following conclusions: firstly, there is currently no unified interpretation of the concept of digital didactics in Russian and foreign literature; secondly, there are quite a large number of diverse interpretations of this term; and thirdly, despite methodological and conceptual differences, we can notice a fundamental commonality of approaches to the definition of "digital didactics", this is a theory of learning that emerged and became widespread in the era of digitalization. 


\subsection{General characteristics of digital didactics}

In a world that is changing literally every day, it is not the task to form skills that comes first, but to master the necessary competencies in this world. Hence the change in the foundations of didactics in general. Meaning didactics appeared at the intersection of psychology and pedagogy at the beginning of the century, the main task of teaching is not to accumulate knowledge, but to fill it with personal meaning [41].

Classical (traditional didactics) includes the following components: principles, goals, content, organizational forms, tools and methods, and competencies. We will consider their main aspects in the discussion of domestic scientific schools, as well as, when possible, highlighting foreign trends. In the last column, the author's notes are presented - the didactic possibilities of digital didactics in the context of meaning didactics. (Table 1).

Table 1. Characteristics of the main components of digital didactics

\begin{tabular}{|c|c|c|}
\hline The main components & Discussion & Authors' note \\
\hline Object and subject & $\begin{array}{l}\text { Object ...the process of education and training implemented using the } \\
\text { capabilities of the digital educational environment (hereinafter referred to as } \\
\text { DEE) } \\
\text { Subject: holistic learning process in the DEE (digital education ecosystem) [4]. } \\
\text { The object..E-learning[26] } \\
\text { - digital didactics-a section of "digital pedagogy", the subject of which is } \\
\text { digital learning[29]. } \\
\text { - "computer didactics -the intersection of traditional didactics and IT. Subject- } \\
\text { learning methods in the context of their computer implementation [30]. } \\
\text {-didactic engineering. Study, development, and design of educational } \\
\text { products[6]. }\end{array}$ & object and subject $[41,44]$ \\
\hline Principles & $\begin{array}{l}\text {-dominance of the learning process, personalization, flexibility and } \\
\text { adaptability, success in learning, interactivity, practice orientation, increasing } \\
\text { complexity, polymodality [4]. } \\
\text { - principles of: activity; communicative, individual approach; favorable } \\
\text { friendly environment [42]. } \\
\text { - preserving the principles of classical pedagogy: visibility, systematicity, } \\
\text { consistency and implementation of innovative technologies: interactivity, } \\
\text { identification, expediency, etc. [43]. } \\
\text { - "didactics of the information society" - the process of complementing } \\
\text { traditional and developing new didactic principles[5]. }\end{array}$ & $\begin{array}{l}\text { the principle of personal- } \\
\text { meaning orientation } \\
{[41,44] \text {. }}\end{array}$ \\
\hline $\begin{array}{l}\text { Goals (expected } \\
\text { results) }\end{array}$ & $\begin{array}{l}\text { - mastering the fundamental core of education; formation of digital } \\
\text { competencies; formation of functional literacy [4]. } \\
\text { - formation and improvement of digital competencies of teachers, students, and } \\
\text { parents [8]. } \\
\text { - Remote acquisition of competencies [26]. } \\
\text {-differentiated goal setting: the potential of IT is not an end in itself, but is used } \\
\text { to achieve new educational goals [42]. } \\
\text { - creation of a technology-equipped learning environment that allows students } \\
\text { to set their own goals and evaluate their progress in their studies[6]. } \\
\text { - acquisition of professional competencies and digital skills[45]. } \\
\text { - reduction of terms of development of educational programs; creation of } \\
\text { individual learning paths; education of a harmoniously developed and socially } \\
\text { responsible person.-the ability of students to set their own learning goals, - the } \\
\text { ability to track and evaluate their own progress in learning, scaling of } \\
\text { educational goals [3]. }\end{array}$ & $\begin{array}{l}\text { Meaning formation. } \\
\text { development of the semantic } \\
\text { sphere }[41,44] \text {. }\end{array}$ \\
\hline Content & $\begin{array}{l}\text {-creation of new digital educational products for training[39]. } \\
\text { - "digital content" [45]. } \\
\text { - designing interactive content: contributing to the educational and creative } \\
\text { activities of students [6]. }\end{array}$ & $\begin{array}{l}\text { integration } \\
\text { of meaning and digital } \\
\text { didactics [46]. }\end{array}$ \\
\hline Tools and methods & $\begin{array}{l}\text { Personalized educational process; digital pedagogical technologies; meta- } \\
\text { digital educational complexes (stimulants, simulators, etc.) [4]. } \\
\text { - the idea of programmed learning, computer software "ACE Project" for } \\
\text { elementary schools in the USA[47]. } \\
\text { - bridging the digital divide, deploying digital infrastructure, digital assessment, } \\
\text { and making educational and methodological materials publicly available [2]. }\end{array}$ & $\begin{array}{l}\text { transforming the methods of } \\
\text { classical didactics on a } \\
\text { meaning basis[41]. }\end{array}$ \\
\hline Technologies & $\begin{array}{l}\text {-universal information and communication technologies (hereinafter referred to } \\
\text { as ICTs), training technologies (digital, digitally born), production (for } \\
\text { professional education) [4]. } \\
\text {-promising technologies of orienting training( cloud computing, Internet of } \\
\text { things) [48]. }\end{array}$ & $\begin{array}{l}\text { didactic technologies that } \\
\text { initiate meaning formation in } \\
\text { students }[41,44,46] . \\
\text { - technologies that initiate } \\
\text { meaning formation in }\end{array}$ \\
\hline
\end{tabular}




\begin{tabular}{|c|c|c|}
\hline & $\begin{array}{l}\text {-technologies of virtual reality, artificial intelligence, blockchain, etc. [2]. } \\
\text { - "Flipped learning" [51]. } \\
\text { "Open class " [23]. } \\
\text { Gamification[23]. }\end{array}$ & $\begin{array}{l}\text { students in the conditions of } \\
\text { digital education. }[49,50] \text {. }\end{array}$ \\
\hline Organizational forms & $\begin{array}{l}\text {-Distance (online) learning; mixed (combined), "inverted learning", adaptive } \\
\text { [4]. } \\
\text {-synchronous/asynchronous [39] } \\
\text { - online Learning [52]. } \\
\text { - electronic learning(E- learning) [32,33]. } \\
\text {-hybrid learning [22]. } \\
\text {-Flexible Online Learning [53]. }\end{array}$ & $\begin{array}{l}\text {-forms that promote self- } \\
\text { regulation of students ' } \\
\text { meanings }[41,44] \text {. } \\
\text {-forms based on value- } \\
\text { meaning choice }[49,50] \text {. }\end{array}$ \\
\hline $\begin{array}{l}\text { The role of the } \\
\text { teacher }\end{array}$ & $\begin{array}{l}\text { Role-playing positions: 1. teacher-student (group): organizer, trainer, developer } \\
\text { of educational trajectories, tutor, game technician, etc. } \\
\text { 2. teacher-digital technologies-student(group) - curator-on-line platforms, web } \\
\text { psychologist, digital footprint analyst, etc. } \\
\text { 3. specialist-digital technologies: methodologist, digital media architect, DSP } \\
\text { developer, etc. [4]. } \\
\text { - integration of roles: teacher, didact, engineer. Introduction of the concept of } \\
\text { didactic engineering [6]. } \\
\text { - teacher - "E-tutor" changing functions from "teaching" to "directing" [26] }\end{array}$ & $\begin{array}{l}\text { - a two-pronged learning } \\
\text { process "subject to subject" } \\
\text { [41]. }\end{array}$ \\
\hline Competencies & $\begin{array}{l}\text {-a model of competencies that includes } 4 \text { types: media competence, } \\
\text { information, technical, and consumer [8]. } \\
\text { - the " } 4 \mathrm{~K} \text { " model of competencies (creativity, critical thinking, cooperation, } \\
\text { and communication) [54]. } \\
\text {-three levels of ICT proficiency: low, medium, high; development of } \\
\text { constructive thinking of teachers [6] } \\
\text { - a model of concepts of advanced education of teachers[55]. }\end{array}$ & $\begin{array}{l}\text { there is no development of } \\
\text { digital competencies in } \\
\text { meaning didactics (authors' } \\
\text { note) }\end{array}$ \\
\hline
\end{tabular}

Analysis of publications on structuring components of didactics in the context of digital didactics allowed us to draw the following conclusions: first, most foreign studies lack a methodological didactic basis, foreign researchers conduct empirical studies of technologies, forms, organization of training sessions, methods and attitudes of students (students) towards the digital transformation of education. secondly, holistic concepts have been developed recently in leading Universities of the Russian Federation and are at the stage of testing, thirdly, there are currently no publications on the study of digital competencies of teachers and students in the context of semantic didactics, and fourthly, difficulties in the analysis are caused by different approaches to the definition of "digital didactics". These and other points made it possible to form a promising research area.

\subsection{Prospects for further research in the field of "digital didactics"}

Analysis of sources on the research topic allowed us to identify the following areas of development that require further consideration:

1. The problem of constant change and updating, the emergence of new interpretations, approaches to the definition of the concept of "digital didactics". Most often, this is due to the author's specialization (teachers, methodologists, administration, computer science specialists, psychologists) [29].

2. Substitution of the phenomenon of digitalization of education by "digitization", that is, the use of traditional methods with the help of communication tools (for example, a lecture in online format).) [4].

3. The modern teacher's choice of technologies, means and methods of teaching in a huge "flow" of information resources, a kind of "unfocused diversity" [47, 55].

4. Exaggeration of the assessment of the capabilities of DSP, electronic resources and in this regard, dependence on their use [56].

5. Social and psychological problems associated with the use of digital tools (changes in higher mental functions, mechanisms of personality formation, ways of relationships with others, etc.) [8].

6. The problem of deformation, changes in the worldview, value-meaning orientations. The emergence of the danger of "dehumanization " [4]. 
7. The problem of the lack of consideration of digital competencies in the context of meaning formation [46].

\section{Conclusions and future directions}

The analysis of domestic and foreign studies allowed us to draw the following conclusions: - due to the pandemic, the number of foreign and Russian studies devoted to digital didactics has increased. This trend is dictated by the challenges of the modern world, the digitalization of education, the socio-psychological characteristics of the modern young generation, numerous digital resources, as well as the requirements of the digital economy for future " digital personnel";

- the results of the review show where research knowledge has already been accumulated, and where further research is needed, and what steps should be taken to develop knowledge on this topic;

- leading Universities of Russia and the world are developing and testing projects of concepts, transformation of classical learning theory into digital didactics;

- despite different views, we can distinguish a conditional General approach to the definition of "digital didactics"- this is a branch of pedagogy, the theory of learning in the context of digitalization of society;

- despite the extensive literature, there is no description of digital competencies in the context of meaning formation, technologies, meaning techniques, etc. that can be used in digital didactics, which provides prospects for future research.

- this research will be useful for graduate students, teachers, psychologists who are taking the first steps in finding information about "digital didactics", as well as for experienced researchers to structure literature sources on the current topic - "digital didactics".

\section{References}

1. A.Yu. Uvarov, I.D. Frumin, Difficulties and prospects of digital transformation of education (Moscow, NRU High School of Economics 2019)

2. I.A. Karlov, V.O. Kovalev, N.A. Kozhevnikov, E.D. Patarakin, I.D. Frumin, A.N. Shvindt, D.O. Shonov, Express analysis of digital educational resources and services for organizing the educational process of schools in a distance form. National Research University Higher School of Economics, Institute of Education, Moscow, NRU High School of Economics, 4(34), 56 (2020)

3. D.S. Ermakov, P.N. Kirillov, Personalized model in digital, Educational policy, 3(79), 132-141 (2019)

4. V.I. Blinov, M.V. Dulinov, E.Yu. Yesenina, I.S. Sergeev, Draft didactic concept for digital vocational education and training, 6 (Moscow, 2019)

5. L.V. Snegireva, University e-learning: methodological problems and didactic principles development. AKTUÁLNÍ PEDAGOGIKA, 4, 9-12 (2017)

6. Tchoshanov Mourat. Engineering of learning: conceptualizing e-didactics, UNESCO inst. for inform. technologies in education, 192 (Moscow, 2013)

7. A.N. Pechnikov, E-didactics: who needs it, why and in what form. Educational technology and society, 4 (2013) https://readera.org/14062510 (Last accessed 2021/02/12)

8. N.V. Dvoryanchikov, T.V. Kalashnikova, L.S. Pechnikova, N.V. Frolova, The use of e-learning in the educational process: problems and prospects, Psychological science and education, 21, 2, 76-83 (2016) doi:10.17759/pse.2016210209 
9. G.U. Soldatova, E.I. Rasskazova, T.A. Nestik, The digital generation of Russia: competence and safety, Moscow, Meaning, 375 (2018)

10. V.N. Dolgopolov, Methodological foundations for studying the influence of modern information technologies on the value-semantic sphere of the individual, North Caucasian psychological bulletin, 13(3), 5-9 (2015)

11. D. Kergel, B. Heidkamp-Kergel, E-Learning, E-Didaktik und digitales Lernen. SpringerLink, 1-56 (2020) DOI: 10.1007/978-3-658-28277-6.

12. https://www.learntechlib.org/p/208392 (Last accessed 2021/02/12)

13. S. Ali, M.A. Uppal, S. Gulliver, A conceptual framework highlighting e-learning implementation barriers. Information Technology \& People, 31(1), 156-180 (2018).

14. S. Arafat, N. Aljohani, R. Abbasi, A. Hussain, M. Lytras, Connections between elearning, web science, cognitive computation and social sensing, and their relevance to learning analytics: A preliminary study. Computers in Human Behavior, 92, 478-486 (2019)

15. D. Benta, G. Bologa, I. Dzitac, E-learning platforms in higher education case study. Procedia Computer Science, 31, 1170-1176 (2014)

16. I. Jahnke, P. Bergström, Digital Didactical Designs as research framework: iPad integration in Nordic schools, Computers \& Education, 113, 1-15 (2017)

17. I. Jahnke, Digital didactical Designs: Teaching and learning in crossaction spaces, 220 (New York, Routledge, 2016)

18. K. Ruthven, The didactical tetrahedron as a heuristic for analysing the incorporation of digital technologies into classroom practice in support of investigative approaches to teaching mathematics, ZDM - The International Journal of Mathematics Education, 44(5), 627-640 (2012)

19. M. Tchoshanov, Engineering of Learning: Conceptualizing e-Didactics, Moscow the UNESCO Institute for Information Technologies in Education, 194 (2013)

20. M. Kangas, P. Siklander, J. Randolph, H. Ruokamo, Teachers' engagement and students' satisfaction with a playful learning environment. Teaching and Teacher Education, 63, 274-284 (2017)

21. M. Koc-Januchta, T. Höffle, G.B. Thoma, H. Prechtl, D. Leutner, Visualizers versus verbalizers: Effects of cognitive style on learning with texts and pictures - an eyetracking study. Computers in Human Behavior, 68, 170-179 (2017)

22. D. Clark, Blended Learning: An Epic White Paper, Epic Group plc., 44 (2003) http://www.alapitvany.oktopusz.hu/domain9/files/modules/module15/261489EC2324 A25.pdf. (Last accessed 2021/02/12)

23. E. King, R. Boyatt, Exploring factors that influence adoption of e-learning within higher education. British Journal of Educational Technology, 46(6), 1272-1280 (2015) https://www.learntechlib.org/p/151955/ (Last accessed 2021/02/12)

24. E. Safapour, S. Kermanshachi, P. Taneja, A Review of Nontraditional Teaching Methods: Flipped Classroom, Gamification, Case Study, Self-Learning, and Social Media. (2019) 10.3390/educsci9040273.

25. G. D'Angelo, From Didactics to E-Didactics - Paradigms, Models and Techniques for e-Learning, 404 (Naples: LIGUORI EDITORE, 2007)

26. I.N. Frolov, E-learning as a form of education in the XXI century. Informatics and Education, 2, 109-110 (Moscow, 2009) 
27. E.V. Shirshov, Electronic didactics in the system of higher education, Innovations in vocational and professional pedagogical education: abstracts of the 9th Russian scientific and practical conference, 42-43 (Moscow, Yekaterinburg, 2002)

28. A.A. Andreev, V.I. Soldatkin, Distance learning: essence, technology, organization, 196 (Moscow, 1999)

29. E.Yu. Ilaltdinova, T.K. Belyaeva, T.K. Lebedeva, Digital pedagogy: features of the evolution of the term in the categorical-conceptual apparatus of pedagogy. Prospects for Science and Education, 4(40), 33-43 (2019) DOI: 10.32744/pse.2019.4.3

30. A.N. Pechnikov, A.N. Shikov, The problem of computer didactics: history, essence and approaches to the solution, Informatics and education, 4, 3-13 (Moscow, 2015)

31. J. Curtis, Bonk The Handbook of Blended Learning: Global Perspectives, Local Designs, Pfeiffer, 8. Clark, D. Blended Learning: An Epic White Paper, 44 (2003)

32. M. Domun, G.K. Bahadur, Design and Development of a Self-Assessment Tool and Investigating its Effectiveness for E-Learning, European Journal of Open, Distance and E-Learning, 17(1), 1-25 (2014) DOI: 10.2478/eurodl-2014-0001

33. G. Dilrukshi, S. Fernando, I. Perera, Factors affecting to effective eLearning: Learners Perspective, Scientific Research Journal (SCIRJ), 2, 42-48 (2014) DOI: 10.1109 / UMEDIA.2015.7297461

34. I. Jahnke, P. Bergström, E. Mårell-Olsson, L. Häll, S. Kumar, Digital Didactical Designs as research framework: iPad integration in Nordic schools. Computers \& Education, 113, 1-15 (2017) https://doi.org/10.1016/j.compedu.2017.05.006

35. C. Hofmeister, M. Pilz, Using E-Learning to Deliver In-Service Teacher Training in the Vocational Education Sector: Perception and Acceptance in Poland, Italy and Germany. Education Sciences, 10(7), 182 (2020)

36. E. Zuanelli, Elearning Content 'Usability': Semiotic and Didactic Parameters in Digital Texts and Textuality, Procedia - Social and Behavioral Sciences, 106, 10391049 (2013) https://doi.org/10.1016/j.sbspro.2013.12.118

37. E. Voevoda, Digital didactics: technologies \& practices. Professional Discourse \& Communication (2020) https://doi.org/10.24833/2687-0126-2020-2-2-89-94

38. L. Zhi-Jiang, N. Tretyakova, V. Fedorov, M. Kharakhordina, Digital Literacy and Digital Didactics as the Basis for New Learning Models Development. International Journal of Emerging Technologies in Learning (iJET). 15(14), 4 (2020) DOI: 10.3991/ijet.v15i14.14669

39. V.I. Toktarova, A.E. Shpak, Digital Pedagogy: Interpretive and Content Analysis, Digital Humanities and Technologies in Education (DHTE 2020). Collection of materials of the All-Russian scientific-practical conference with international participation. 19-21 November 2020, 28-33 (2020) eLIBRARY ID: 44342523

40. A.A. Verbitsky, Digital learning: problems, risks and prospects, Electronic scientific journal "Homo Cyberus", 1(6), (2019) URL: http://journal.homocyberus.ru/Verbitskiy_AA_1_2019 (Last accessed 2021/02/22)

41. I.V. Abakumova, A.M. Kukulyar, V.T. Fomenko, Smyslodidaktika as a systematic embodiment of the general theory of meaning in the practice of the educational process. Russian psychological journal, 11(3), 24-32 (2014) https://doi.org/10.21702/rpj.2014.3.2

42. S.A. Shchennikov, Didactics of e-learning, Higher education in Russia, 12, 83-90 (2010) 
43. L.V. Lavrent'eva, E.V. Yashkova, V.A. Lavrent'ev, Prerequisites for the transition to digital pedagogy in Russian conditions, Problems of modern pedagogical education, 59-2, 152-156 (2018)

44. I.V. Abakumova, L.V. Kosikova, Features of the semantic sphere of adolescents in the conditions of inclusive education. Russian psychological journal, 6(5), 7-14 (2009) https://doi.org/10.21702/rpj.2009.5.1

45. Zh. Nurbekova, B. Baigusheva, The Impact of Digital Transformation of Education on the formation of Digital Didactics. Bulletin of the L.N. Gumilyov Eurasian National University. Pedagogy. Psychology. Sociology Series, 130, 96-101 (2020) 10.32523/2616-6895-2020-130-1-96-101.

46. S.P. Bezolyuk, Meaning formation as a component of the development of digital competences of adolescents, Scientific-methodical electronic journal "Concept", 12, 41-52 (2020) http://e-koncept.ru/2020/201087.html (Last accessed 2021/02/22)

47. A.N. Dzhurinsky, Digital Education in Western Europe and the USA: Hopes and Reality, Siberian Pedagogical Journal, 3, 162-167 (2019)

48. S.F. Sergeev, Methodological problems of e-Learning didactics, Open education, 3(110), 28-36 (2015) https://doi.org/10.21686/1818-4243-2015-3(110-28-36 (Last accessed 2021/02/25)

49. S. Bezoluk, E. Azarko, V. Sannikova, O. Derezko, The initiation of the students' meaning formation via the meaning essay E3S Web Conf. 210, 18059 (2020) DOI: $10.1051 / \mathrm{e} 3$ sconf/202021018059

50. I. Abakumova, N. Mironenkova, D. Penkov, Sense techniques addressed to the student's subjective experience as the basis of his value-semantic choice on the example of mathematics. Russian psychological journal, 16(2), 63-80 (2019) https://doi.org/10.21702/rpj.2019.2.4

51. B. Prevalla, H. Uzunboylu, Flipped Learning in Engineering Education, 656-661 (2019) DOI:10.18421/TEM82-46

52. I. Dhull, S. Arora, Online Learning, 3, 32-34 (2019)

53. L. Singh, R. Thakur, M.T.V. Nagaraju, Online Learning Platforms for Flexible Learning in Educational Framework (2019)

54. M.A. Pinskaya, A.M. Mikhailova, Competencies "4K": formation and assessment in the lesson: Practical recommendations, 76 (Moscow, Corporation "Russian textbook", 2019)

55. L.M. Andryukhina, N.V. Lomovtseva, N.O. Sadovnikova, Concepts of digital didactics as the basis for the design of advanced education for vocational education teachers, Vocational education and the labor market, 1(40), 30-43 (2020)

56. A.M. Magomedov, Problems and trends in the development of digital education, Pedagogy and education, 2, 134-142 (2019) DOI 10.7256/2454-0676.2019.2.27084. 